\title{
19. FOSSIL PLANTS AND OTHER ORGANIC DEBRIS IN CRETACEOUS SEDIMENTS FROM DEEP SEA DRILLING PROJECT LEG 80: THEIR PALEOENVIRONMENTAL SIGNIFICANCE AND SOURCE POTENTIAL ${ }^{1}$
}

\author{
D. J. Batten, Department of Geology and Mineralogy, Aberdeen University \\ G. T. Creber, Department of Botany, University of London \\ and \\ Zhou Zhiyan, Institute of Geology and Paleontology, Academia Sinica, Nanjing ${ }^{2}$
}

\begin{abstract}
The lower part of the syn-rift Barremian-?Hauterivian section at Site 549 contains a large amount of acid-resistant land-derived organic matter that, as elsewhere in the Cretaceous sediments of the IPOD Leg 80 sites, is thermally immature. This plant debris was derived from a vegetation made up of many species of pteridophytes and gymnosperms. The palynofacies indicate that the sediments were deposited in shallow marginal and nonmarine environments and that the climate was probably warm temperate and fairly moist at the time. Source potential for gas is suggested at some horizons. Most of the younger Lower Cretaceous sediments at this and the other sites were deposited in more open marine conditions. Although they generally contain less organic matter, land plant remains continue to comprise a major part of the palynofacies. The Upper Cretaceous sediments were mainly deposited in well oxygenated conditions and are organically lean. However, stratigraphically restricted dark-colored shales at Sites 549 to 551 contain relatively large quantities of amorphous detritus of at least partly marine origin. These characteristics are suggestive of deposition during periods of restricted circulation and also of source potential for oil and gas if maturation levels had been higher.
\end{abstract}

\section{INTRODUCTION}

During IPOD Leg 80, four holes were drilled on and adjacent to the sediment-starved Goban Spur on the continental margin of Ireland (Fig. 1). This topographic feature is over a basement high that is a submarine extension of Cornwall. It is relatively shallow (maximum water depth: $2000 \mathrm{~m}$ ), broad, and smooth, but it deepens abruptly along the Pendragon Escarpment (Figs. 2 and 3). The objectives of the leg included the determination of (1) the subsidence history of the continental and oceanic basement near their junction, (2) the ages of a series of seismic unconformities, and (3) the environments of deposition of the syn- and post-rift sediments.

Earlier drilling during IPOD Leg 48 in the region of the Bay of Biscay was concentrated on the Armorican continental margin (Fig. 1). An unconformity separating the syn- and post-rift sediments was encountered at Sites 401 and 402 (Montadert, Roberts, et al., 1979). Site 401 revealed that Aptian shallow water chalks overlay the unconformity, and lower Aptian limestones at Site 402 were determined to belong to the syn-rift sequence. All pre-Aptian rocks in the region were therefore considered to represent possible syn-rift deposits. The Leg 80 drilling results substantiate this. Another unconformity often separates Upper Cretaceous chalks from Aptian-Albian shales, as at Site 400, and has been attributed to major sea level and other oceanographic changes during the Cenomanian (Vail et al., 1977).

\footnotetext{
${ }^{1}$ Graciansky, P. C. de, Poag, C. W., et al., Init. Repts. DSDP, 80: Washington (U.S. Govt, Printing Office).

Addresses: (Batten) Department of Geology and Mineralogy, Marischal College, Aberdeen University, Aberdeen, United Kingdom; (Creber) Department of Botany, Bedford College, University of London, London, United Kingdom; (Zhiyan) Institute of Geology and Paleontology, Academia Sinica, Chi-Ming-Ssu, Nanjing, Peoples Republic of China.
}

This chapter is concerned with the acid-resistant organic content of the Cretaceous strata above and below these unconformities. For each site a stratigraphic and sedimentological summary based on data provided by the Leg 80 scientific party is followed by comments on the organic matter recovered and its paleoenvironmental significance. Sections that suggest source potential for petroleum are also indicated, and some of the palynofacies and phytoclasts are illustrated. Research on the material continues. This brief summary of results to date will be followed in due course by a longer article containing descriptions of a variety of cuticles and palynomorphs, a miospore-based biostratigraphic synthesis, and further paleoenvironmental discussion. The dinoflagellate cysts are discussed by Fauconnier in this volume.

\section{METHODS}

The organic matter was separated from the rest of the material by using the laboratory method outlined below (for details, see Batten and Morrison, 1983). Samples of $5 \mathrm{~g}$ were digested first in dilute hydrochloric acid and then in 58 to $62 \%$ HF. After neutralization, some of the "kerogen" extracted was mounted on a slide with glycerine jelly. The remainder of the residue, if a sufficient quantity was available, was subjected to brief ultrasonic and oxidative treatment ( $<2 \mathrm{~min}$. of each) and filtered by using a sintered glass funnel (Porosity 2) fitted to a Buchner flask with side-arm and hand-bellows attached. A second slide was then prepared.

Usually one sample was examined from each core, although if the material was available and the lithology was likely to yield palynomorphs, two or more were studied. Where the lithology looked unpromising only a few samples were processed. The positions and depths of the samples are listed in Table 1.

Wood fragments, cuticles, and megaspores were isolated from several cores from Site 549, cleared of adhering mineral detritus, and examined under a scanning electron microscope; some are illustrated in Plates 1 to 5. Fields of view of a few of the slides used in the palynofacies analysis are illustrated in Plates 6 and 7, and selected data from these analyses are plotted in Figures 4 and 5 . 


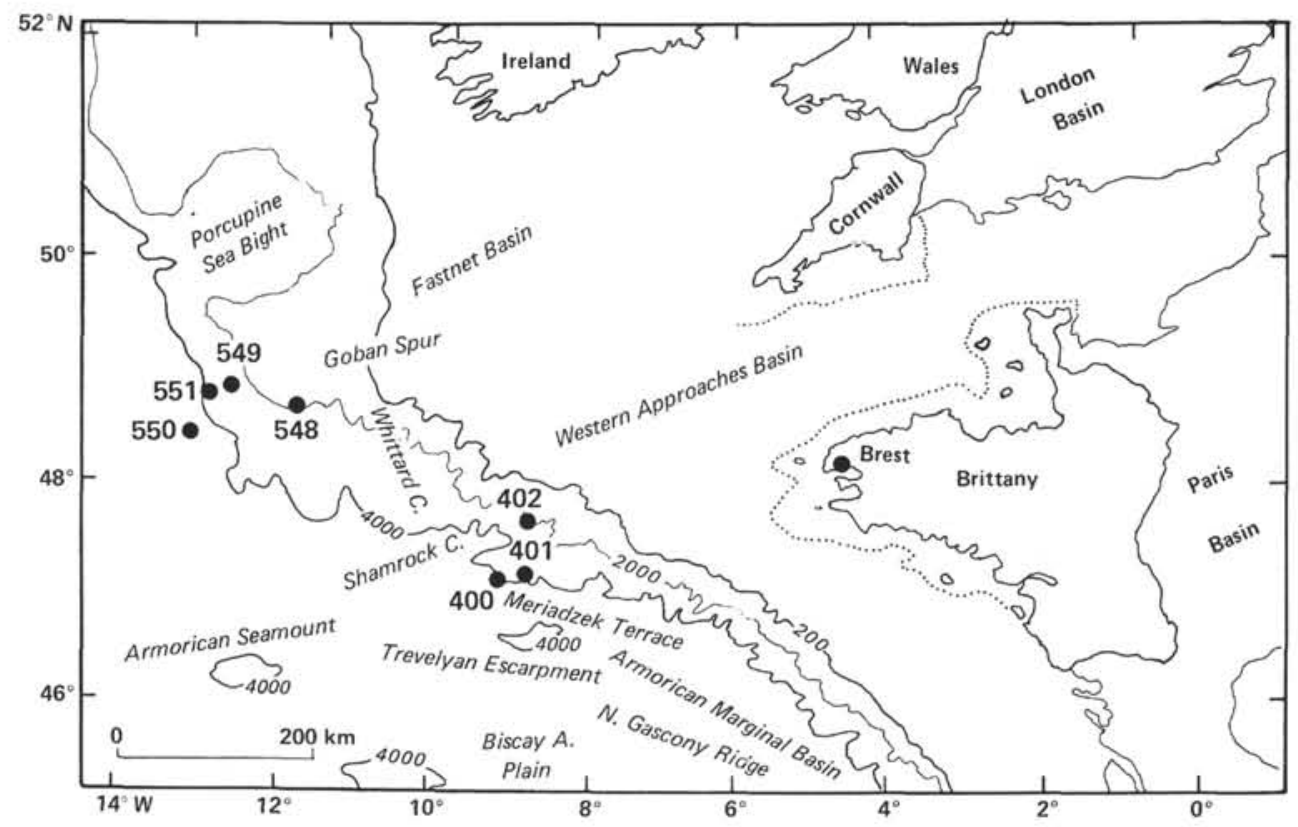

Figure 1. General geography and approximate location of IPOD drill sites in the northern Bay of Biscay region (based in part on fig. 1 of Montadert, Roberts, De Charpal, et al., 1979). Bathymetry in m.

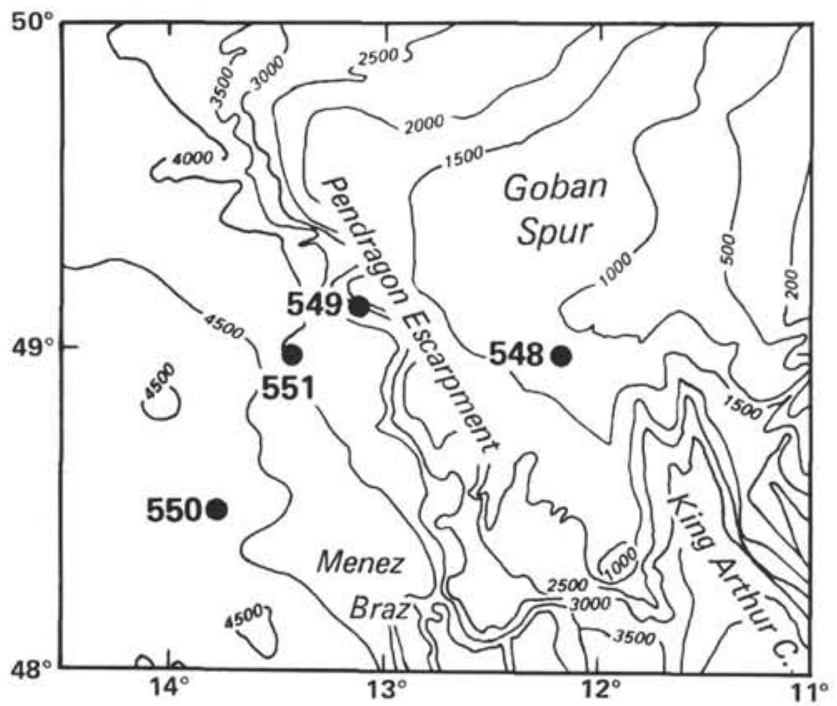

Figure 2. Bathymetry, major topographic features, and positions of IPOD Sites 548 to 551 in the northern Biscay region (based in part on fig. 2 of Montadert, Roberts, De Charpal, et al., 1979).

\section{SITE 548}

Site 548 is on the sloping upper surface of the Goban Spur (Figs. 2 and 3). The strata that overlie the Hercynian basement comprise $60 \mathrm{~m}$ of white bioturbated chalks containing upper Campanian, Maestrichtian, and Danian acid-soluble (i.e., nonpalynological) micro- and nannofossils. The sediments accumulated at a slow average rate (calculated to be about $7.3 \mathrm{~m}$ per m.y.) in well oxygenated outer sublittoral to upper bathyal environments. A disconformity separates the Danian chalk from lower Eocene clays and marls.

Nannofossil chalks are generally organically lean and, as expected, the two samples processed proved to be devoid of palynomorphs (Fig. 5). The almost complete absence of plant matter in the slides indicates that there was little terrestrial input to the site during the Campanian and Maestrichtian. The only phytoclasts present are small black oxidized particles. Had much larger samples been available a few dinoflagellate cysts and miospores might have been recovered, however.

\section{SITE 549}

Site 549 is near the Pendragon Escarpment, which truncates the seaward slope of the Goban Spur (Figs. 2 and 3). The cores recovered revealed a 290 -m syn-rift sequence of Barremian and perhaps partly Hauterivian rocks. The sediments apparently accumulated rapidly $(60 \mathrm{~m} / \mathrm{m}$.y.) during a gradual marine transgression over an elevated basement block.

The lowest $150 \mathrm{~m}$ of the sequence consists of interbedded noncalcareous and calcareous mudstones that contain abundant land plant debris and, at several horizons, assemblages of microfossils that indicate hyposaline conditions. This section is overlain by $40 \mathrm{~m}$ of vuggy recrystallized skeletal packstones and wackestones, followed by $120 \mathrm{~m}$ of calcareous sandy mudstones that contain planktonic foraminifers and nannoplankton typical of open marine/outer neritic paleoenvironments.

An unconformity separates the Barremian section from lower Albian rocks; the uppermost Barremian, most (perhaps all) of the Aptian, and possibly part of the Albian are missing. Post-rift Albian sedimentation was rapid $(67.5 \mathrm{~m} / \mathrm{m} . \mathrm{y}$.$) . It began in shallow water, but depths$ gradually increased as a result of the subsidence of the Goban Spur and a rise in sea level. The succession consists of a 7-m unit of undated hard sandy dolosparite (perhaps an Aptian remnant) followed by $185 \mathrm{~m}$ of gray calcareous siltstones that contain middle to outer sublittoral micro- and nannofossils and the scattered remains 


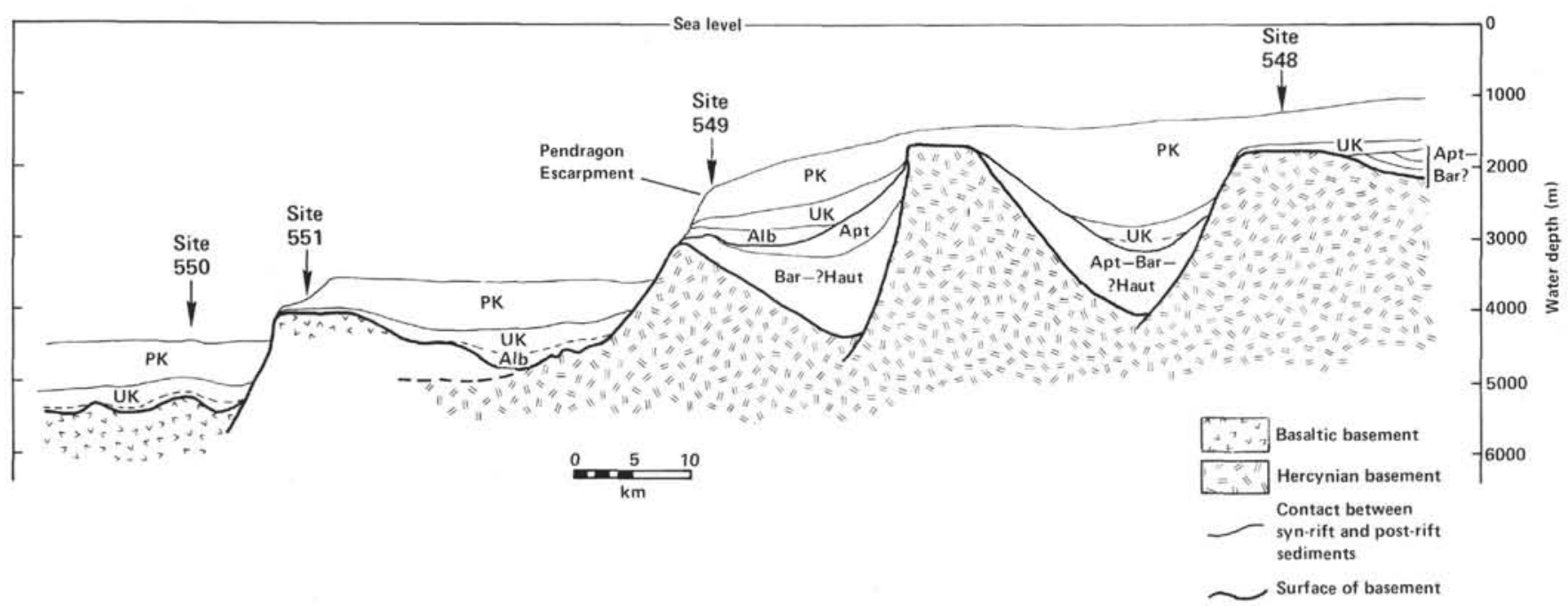

Figure 3. Schematic composite dip section across the Goban Spur showing the main Cretaceous sedimentary units. Haut $=$ Hauterivian, Bar $=$ Barremian, Apt $=$ Aptian, Alb $=$ Albian, $\mathrm{UK}=$ Upper Cretaceous, $\mathrm{PK}=$ post-Cretaceous.

Table 1. Positions and depths of samples examined for palynomorphs and plant debris.

\begin{tabular}{|c|c|c|c|c|c|}
\hline \multirow{2}{*}{$\begin{array}{c}\text { Sample } \\
\text { (interval in } \mathrm{cm} \text { ) }\end{array}$} & \multicolumn{2}{|c|}{$\begin{array}{l}\text { Sub-bottom } \\
\text { depth (m) }\end{array}$} & \multirow{2}{*}{$\begin{array}{c}\text { Sample } \\
\text { (interval in } \mathrm{cm} \text { ) }\end{array}$} & \multicolumn{2}{|c|}{$\begin{array}{l}\text { Sub-bottom } \\
\text { depth }(\mathrm{m})\end{array}$} \\
\hline & Core & Sample & & Core & Sample \\
\hline $548 \mathrm{~A}-31-2,16-17$ & 490.50 & 492.17 & $549-80-1,104-105$ & 861.00 & 862.05 \\
\hline $548 \mathrm{~A}-32-2,81-82$ & 500.00 & 502.32 & $549-80-1,118-119$ & 861.00 & 862.19 \\
\hline $549-22-2,106-107$ & 388.50 & 391.07 & $549-80-1,130-131$ & 861.00 & 862.31 \\
\hline $549-23-4,53-54$ & 398.00 & 403.04 & $549-81-1,126$ & & \\
\hline $549-25-2,25-27$ & 417.00 & 418.76 & $549-81-2,53-54$ & & \\
\hline $549-28-2,26-28$ & 445.50 & 447.27 & $549-82-2,64-66$ & 874.50 & 876.65 \\
\hline $549-32-1,26-27$ & 483.50 & 483.77 & $549-83-1,70-71$ & 879.00 & 879.71 \\
\hline $549-33, \mathrm{CC}, 6-7$ & 493.00 & 493.10 & $549-83-2,8-9$ & & \\
\hline $549-34-1,51-52$ & 502.50 & 503.02 & $549-84-1,106-107$ & & \\
\hline $549-35-1,43-44$ & 512.00 & 512.44 & $549-84-2,117-118$ & & \\
\hline $549-36-1,19-20$ & 521.50 & 521.70 & $549-85-2,78-79$ & 888.00 & 890.28 \\
\hline $549-37-2,33-34$ & & & $549-86-1,0-125$ & & \\
\hline $549-43-4,54-57$ & 578.50 & 583.56 & $549-86-2,20-22$ & 897.00 & 898.71 \\
\hline $549-44-2,0-2$ & 588.00 & 589.51 & $549-86-2,95-145$ & & \\
\hline $549-45-2,62-63$ & 597.50 & 599.63 & $549-87-2,52-53$ & & \\
\hline $549-46-4,92-93$ & 607.00 & 612.42 & $549-88-2,74-75$ & 910.50 & 912.74 \\
\hline $549-49-2,88-89$ & & & $549-89-1,50-51$ & 919.50 & 920.01 \\
\hline $549-54-4,23-24$ & 683.00 & 687.74 & $549-89-1,128-130$ & & \\
\hline $549-55-4,120-121$ & 692.00 & 697.71 & $549-90-2,110-111$ & 928.50 & 931.10 \\
\hline $549-56-2,52-53$ & 701.00 & 703.03 & $549-90-2,110-117$ & & \\
\hline $549-57-2,56-57$ & 710.00 & 712.07 & $549-91-1,9-14$ & 937.50 & 937.62 \\
\hline $549-58-6,84-85$ & & & $549-91-1,18-20$ & 937.50 & 937.69 \\
\hline $549-59-2,44-45$ & 728.00 & 729.95 & $549-91-1,84-85$ & & \\
\hline $549-60-4,80$ & & & $549-91-2,23-25$ & 937.50 & 939.24 \\
\hline $549-60-5,145-147$ & 737.00 & 744.46 & $549-92-1,108-109$ & 946.50 & 947.59 \\
\hline $549-60-6,73-74$ & 737.00 & 745.24 & $549-92-2,36-37$ & & \\
\hline $549-61-2,106-108$ & 746.00 & 748.57 & $549-93-1,31-34$ & 955.50 & 955.83 \\
\hline $549-61-4,114-115$ & 746.00 & 751.65 & $549-93-1,101-102$ & 955.50 & 956.52 \\
\hline $549-70-1,35-36$ & 794.50 & 794.85 & $549-93-2,93-94$ & & \\
\hline $549-70-1,47-48$ & 794.50 & 794.98 & $550 \mathrm{~B}-3-1,90-91$ & 475.00 & 475.91 \\
\hline $549-70-1,50-51$ & 794.50 & 795.01 & $550 \mathrm{~B}-4-5,85-86$ & & \\
\hline $549-70-1,61-62$ & 794.50 & 795.12 & $550 \mathrm{~B}-9-2,25-26$ & 532.00 & 533.76 \\
\hline $549-72-2,101-102$ & & & $550 \mathrm{~B}-11-4,15-16$ & 551.00 & 555.66 \\
\hline $549-73-1,101-103$ & 806.50 & 807.52 & $550 \mathrm{~B}-13-6,3-5$ & 570.00 & 577.54 \\
\hline $549-73-2,22-23$ & 806.50 & 808.23 & $550 \mathrm{~B}-14-1,127-128$ & 579.50 & 580.78 \\
\hline $549-74-2,34-35$ & 811.00 & 812.85 & $550 \mathrm{~B}-15-2,144-145$ & 589.00 & 591.95 \\
\hline $549-75-2,54-55$ & 816.00 & 818.05 & $550 \mathrm{~B}-17-2,72-73$ & 608.00 & 610.23 \\
\hline $549-75, \mathrm{CC}, 24-25$ & 816.00 & 820.23 & $550 \mathrm{~B}-21-2,107-108$ & 644.00 & 646.58 \\
\hline $549-76-2,52-53$ & 825.00 & 827.03 & $550 \mathrm{~B}-22-6,58-59$ & 653.00 & 661.09 \\
\hline $549-78-1,31-32$ & 843.00 & 843.32 & $550 \mathrm{~B}-24-3,40-41$ & 671.00 & 674.41 \\
\hline $549-79-1,83-84$ & 852.00 & 852.84 & $550 \mathrm{~B}-25-4,70-71$ & 680.00 & 685.21 \\
\hline $549-80-1,82-83$ & 861.00 & 861.83 & $551-4-2,94-95$ & 123.50 & 125.95 \\
\hline
\end{tabular}

of belemnites. The upper part of the unit comprises an irregular alternation between calcareous and clay-rich beds.

A hiatus separates middle Albian from upper Cenomanian strata. The sedimentation rate during the Late
Cretaceous was low ( $3.2 \mathrm{~m} / \mathrm{m} . \mathrm{y}$.$) . Only 100 \mathrm{~m}$ of variously colored chalks accumulated, and there are two, and possibly more, stratigraphic gaps in the section. A thin (1.4-m) Turonian interval contains some black shale laminations. The Cretaceous/Tertiary boundary is a disconformity between upper Maestrichtian and upper $\mathrm{Pa}$ leocene strata.

Numerous layers in the syn-rift section contain megascopic remains of plants. Pieces of wood are preserved as both vitrinite and fusinite (Plates 1 and 2); those that have been identified all belong to the conifer family Cheirolepidiaceae. Fragments of foliage have been found. Most of these also show cheirolepidiaceous characteristics-the cuticles suggest the presence of perhaps five species belonging to this family-but some are referable to the Ginkgoales, Bennettitales, and other gymnosperm groups (Plates 3 and 4).

Many of the palynological preparations contain large quantities of wood and other plant tissues. Gymnosperm (particularly bisaccate) pollen is abundant, but triradiate spores are also numerous and relatively varied in morphology. A few megaspores are present in some of the preparations; two species have been examined under the scanning electron microscope and are illustrated herein (Plate 5).

The overall composition of the spore, pollen, and plant debris assemblages indicates a mixed pteridophyte-gymnosperm vegetation, and the abundance of the remains suggests that the site of deposition was relatively close to land. At this time angiosperms are unlikely to have formed more than a small part of the flora. The assemblages also suggest that the climate was probably similar to that in the Wealden area of southern England during the Hauterivian and Barremian, that is, warm temperate and relatively moist (Sladen and Batten, in press).

It is likely that the depositional environments were generally well oxygenated. The fair to good preservation of most of the plant remains may be attributed to rapid sedimentation and burial. Except for dinoflagellate cysts 


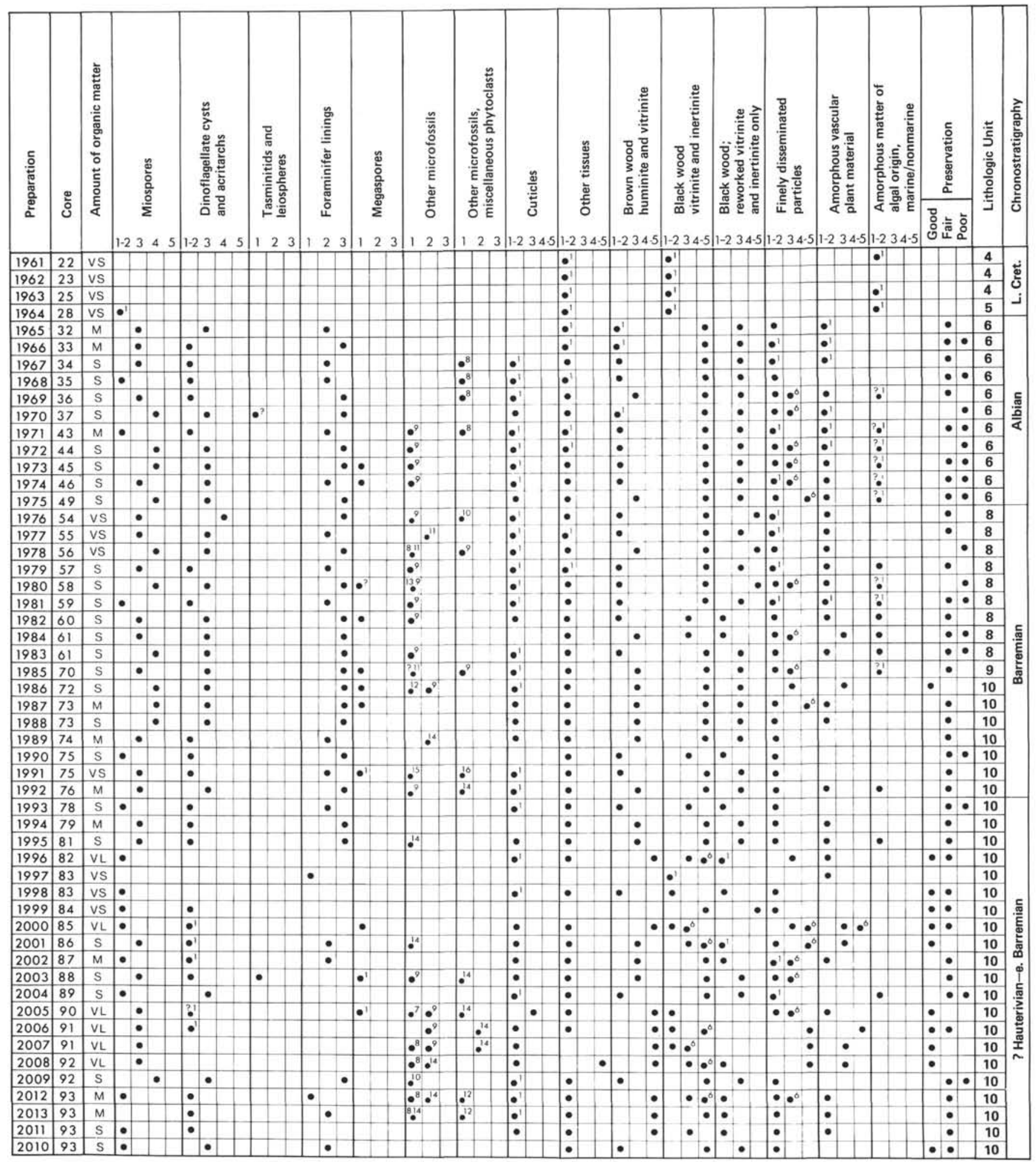

Figure 4. Selected palynofacies data for samples from the Cretaceous of Site 549. Amount of organic matter (recovered from $5 \mathrm{~g}$ samples): VS = very small, $\mathrm{S}=$ small, $\mathrm{M}=$ moderate, $\mathrm{VL}=$ very large. Abundances: $1=$ trace, $2=$ rare to present, $3=$ common, $4=$ frequent, $5=$ abundant to dominant. Qualifiers: $6=$ first slide only, $7=$ Schizophacus spp., $8=$ annuli and sporangia, $9=$ fungal remains, $10=$ scolecodonts, 11 = arthropod remains, 12 = spore and pollen masses, 13 = palynomorphs (incertae sedis), $14=$ resinous bodies, $15=$ Schizosporis spp. Lithologic units are from information made available by the Leg 80 scientific party. 


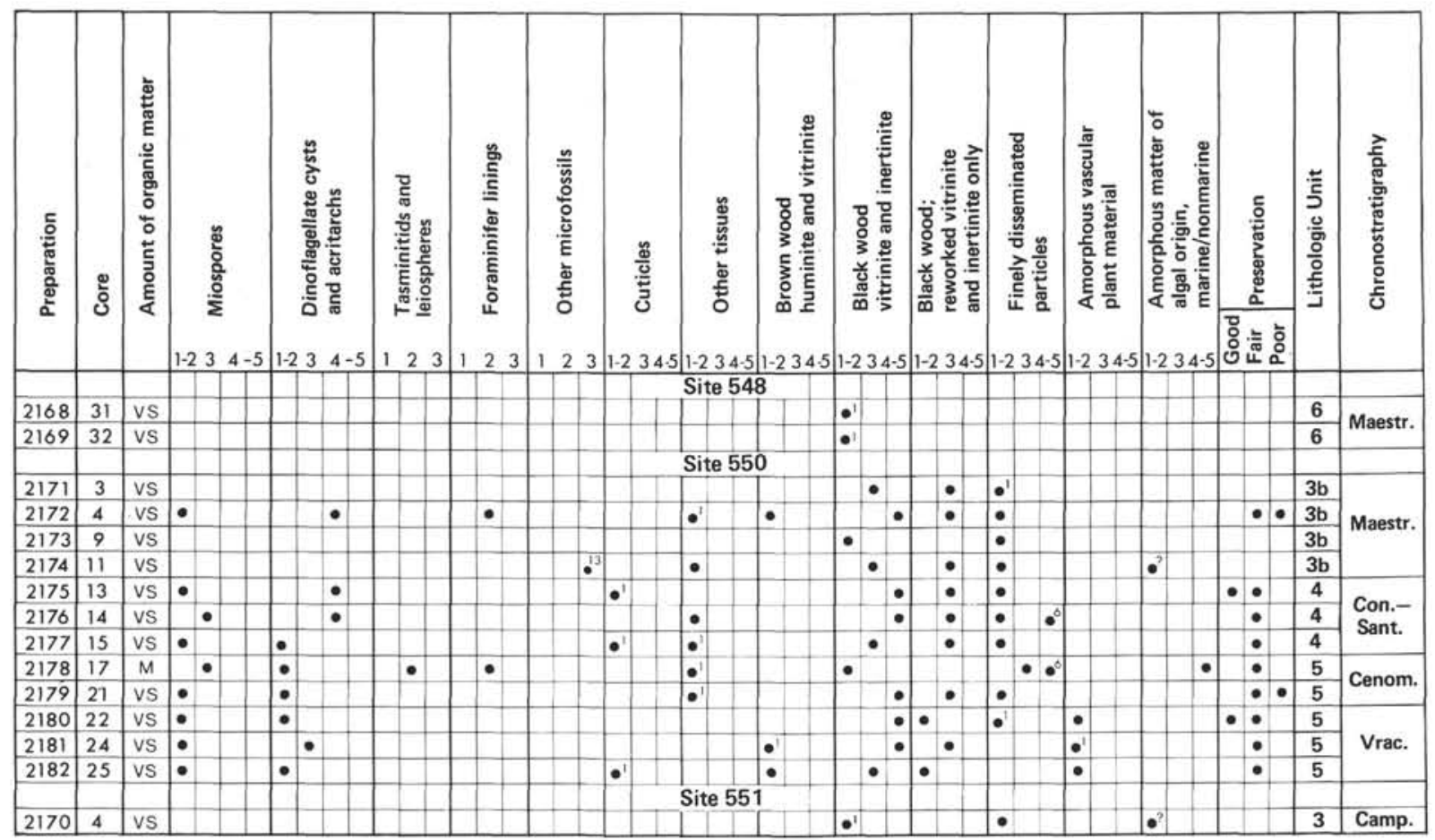

Figure 5. Selected palynofacies data for samples from the Cretaceous sediments of Sites 548, 550, and 551. Megaspores were absent entirely, and no microfossils other than those belonging to the first four categories were found. For a detailed explanation see Figure 4.

and foraminiferal linings, marine plants and animals appear to have made a minimal contribution to the acidresistant organic component of the sediments. Cysts, linings, or both occur in most of the samples processed (Plate 6, Fig. 1), but numerically they are usually subordinate to miospores.

Several preparations were made from sediments within the lowest $85 \mathrm{~m}$ of the syn-rift sequence. There is no evidence of marine influence on the depositional environment in four of them (those from Cores $82,90,91$, and 92; Plate 6, Figs. 2-4), and in several others marine indicators are scarce (Fig. 4 and Plate 7, Figs. 1 and 2). It is within this interval that the facies richest in organic material were encountered; all contain scattered megascopic plant remains. From the viewpoint of petroleum generation, the pale colors of the palynomorphs indicate, as elsewhere in the Cretaceous sediments of the Leg 80 sites, that the organic matter is immature, although several levels may be potential sources for gas.

Above Lithologic Unit 10 (Fig. 4), samples from the syn-rift section yielded only small amounts of organic matter, and the palynofacies are similar in general to those of the post-rift Albian (Unit 6, Fig. 4 and Plate 7, Figs. 3-5). Marine and nonmarine microfossils are common in both sequences. Much of the associated plant debris comprises black woody and coaly particles; the bulk of the latter may be reworked. Amorphous substances of marine origin are scarce. Overall, deposition in oxidizing conditions is indicated.

The Upper Cretaceous strata contain very little organic matter. Only two long-ranging miospores were recovered from a Cenomanian sample, and the three samples from shallower horizons (Fig. 4) proved to be entirely devoid of palynomorphs. Deposition in well oxygenated conditions is likely except for a brief period when circulation was apparently restricted. This phase is manifested by a very thin ?Turonian black shale from which, unfortunately, no material was made available for palynological study.

\section{SITE 550}

Site 550 is located on the abyssal plain some $10 \mathrm{~km}$ southwest of the seaward margin of the Goban Spur (Figs. 2 and 3). The basal sediments at the site are deepwater pelagic carbonates that are interbedded with basalt flows and pillows. Foraminifer and nannofossil evidence suggests that they are no older than late Albian. The sediments overlying the youngest pillows, which are at an estimated depth of about $1900 \mathrm{~m}$, were deposited during the latest Albian (Vraconian).

Above, light calcareous and dark, often laminated mudstones compose a lower to middle Cenomanian succession and suggest a sediment accumulation rate of about $13 \mathrm{~m} / \mathrm{m}$.y. A disconformity between middle Cenomanian and Coniacian-Santonian rocks is marked by a sharp change from a light greenish gray calcareous unit showing weak red mottling to dark reddish brown noncalcareous facies. The mixed calcareous and carbonate-depleted sediments that make up the younger sequence accumulated at a low rate $(<1-2 \mathrm{~m} / \mathrm{m}$.y.), the latter presumably below the carbonate compensation depth (CCD). Undated noncalcareous mudstones above 
are separated from calcareous ?Campanian and Maestrichtian strata by an erosional unconformity; the lower and middle Campanian are thought to be missing.

The latest Cretaceous to early Tertiary interval displays an alternation of marly nannofossil chalk with turbidite and mud-flow deposits. The Maestrichtian-Danian boundary occurs within an uninterrupted 80 -m sequence of abyssal chalks.

Except for the black shale horizons, the Upper Cretaceous strata at the other Leg 80 sites yield few plant microfossils. A much greater part of the Upper Cretaceous section at Site 550 is palynologically productive. All of the Cenomanian and Coniacian-Santonian samples that were processed, as well as those from the Vraconian interval (Lithologic Units 4 and 5, Fig. 5), yielded miospores and phytoplankton, although, with the exception of Core 17 , the total recovery of organic material was low. Together with the general aspect of the palynofacies, this suggests that deposition occurred in an open marine environment.

The sample from Core 17 released an abundance of amorphous matter of mixed, but probably mostly marine, origin. The sample is from one of several thin, laminated black shales within the Cenomanian (Unit 5). Conditions must have been more restricted (anoxic) when these sediments were deposited. The palynofacies suggest moderate potential for oil and gas.

Of the four younger ?Campanian-Maestrichtian samples processed, three proved to be devoid of microfossils, as expected. However, one from Core 4 yielded a relatively large number of dinoflagellate cysts and a small miospore assemblage of limited diversity. Open marine sedimentation is again indicated.

\section{SITE 551}

The light-colored chalks that rest on the basaltic flows and pillows at Site 551 (Fig. 3) were deposited in bathyal conditions during the late Cenomanian. The whole Upper Cretaceous section is only $41.5 \mathrm{~m}$ thick, a circumstance attributable to very low sediment accumulation rates and the presence of unconformities. A major stratigraphic break occurs between the lower Turonian deposits, which include a black shale rich in organic matter equivalent to that encountered at Site 549, and an upper Campanian to lower Maestrichtian sequence. This in turn is overlain unconformably by a very thin $(5-\mathrm{m})$ upper Paleocene to lowest Eocene unit.

The few samples made available from this abbreviated Cretaceous succession look unpromising from the palynological viewpoint. The single specimen processed (Fig. 5) proved to be barren of microfossils; only a few black oxidized particles and a trace of amorphous matter of uncertain origin were recovered.

\section{CONCLUSIONS}

The largest, most diverse, and best preserved miospore assemblages are all from the lowest $85 \mathrm{~m}$ of the syn-rift Barremian-?Hauterivian section at Site 549. Megaspores, fragments of wood and leafy shoots, and a few seeds (not considered herein) were also encountered in this interval. Mainly marginal to nonmarine sedimentation is indicated. The adjacent land mass supported a mixed pteridophyte and gymnosperm vegetation. The younger syn-rift and Albian post-rift sediments at this site accumulated in a more open marine situation.

Black shale horizons occur in the Upper Cretaceous sediments at Sites 549 to 551 . They suggest deposition in anoxic environments when water circulation was temporarily restricted. All the other post-rift sediments accumulated in well oxygenated conditions. As a result, most contain very little organic matter. The uppermost Albian-Cenomanian and Coniacian-Santonian sequences at Site 550 yielded assemblages of dinoflagellate cysts and miospores, but elsewhere these palynomorphs proved to be scarce.

Some of the lower syn-rift deposits at Site 549 are rich enough in land plant debris to expect gas generation, given a greater depth of burial and thus higher organic maturity. The limited palynological data on the black shale units suggest that these have source potential for both oil and gas. The colors of the palynomorphs, however, indicate that all the organic matter recovered is insufficiently mature for any significant generation of hydrocarbons to have taken place.

\section{ACKNOWLEDGMENTS}

Lithologic, biostratigraphic, and other data (such as the rates of deposition quoted) on the Cretaceous strata which were made available to DJB by the Leg 80 scientific party have helped to put the study of dispersed sedimentary organic matter recovered from the Leg 80 sites into perspective. Figure 3 is based on a diagram provided. The samples were processed for palynological examination by Mrs. L. Morrison. K. L. Alvin is thanked for his comments on the cheirolepidiaceous wood. The paper was reviewed by Professor W. G. Chaloner and Dr. C. P. Sladen.

\section{REFERENCES}

Alvin, K. L., Fraser, C. J., and Spicer, R. A., 1981. Anatomy and palaeoecology of Pseudofrenelopsis and associated conifers in the English Wealden. Palaeontology, 24:759-778.

Batten, D. J., 1979. Miospores and other acid-resistant microfossils from the Aptian/Albian of Holes 400A and 402A, DSDP-IPOD Leg 48, Bay of Biscay. In Montadert, L., Roberts, D. G., et al., Init. Repts. DSDP, 48: Washington (U.S. Govt. Printing Office), 579-587.

Batten, D. J., and Morrison, L., 1983. Methods of palynological preparation for palaeoenvironmental, source potential and organic maturation studies. Bull. Norw. Pet. Direct., 2:35-53.

Marcinkiewicz, T., 1979. Fungi-like forms on Jurassic megaspores. Acta Palaeobotan., 20:123-128.

Montadert, L., Roberts, D. G., et al., 1979. Init. Repts. DSDP, 48: Washington (U.S. Govt. Printing Office).

Montadert, L., Roberts, D. G., De Charpal, O., and Guennoc, P., 1979. Rifting and subsidence of the northern continental margin of the Bay of Biscay. In Montadert, L., Roberts, D. G., et al., Init. Repts. DSDP, 48: Washington (U.S. Govt. Printing Office), 10251060.

Sladen, C. P., and Batten, D. J., in press. Source-area environments of Uppermost Jurassic and Lower Cretaceous sediments in Southeast England. Proc. Geol. Assoc., 95.

Vail, P. R., Mitchum, R. M., Jr., and Thompson, S., III, 1977. Global cycles of relative changes of sea level. In Payton, C. E. (Ed.), Seismic Stratigraphy-Applications to Hydrocarbon Exploration. Mem. Am. Assoc. Pet. Geol., 26:83-97.

Date of Initial Receipt: March 14, 1983

Date of Acceptance: August 12, 1983 

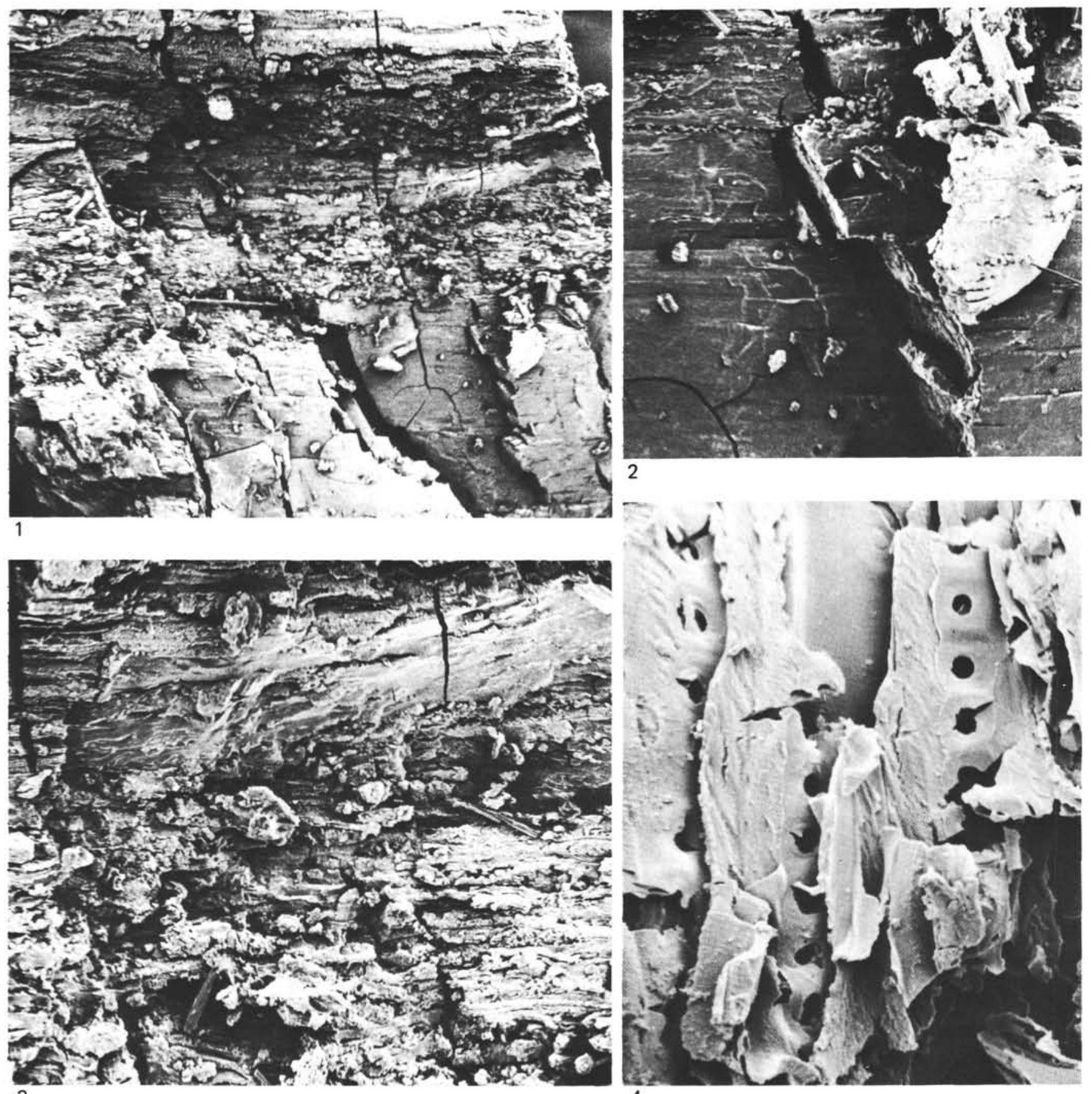
3

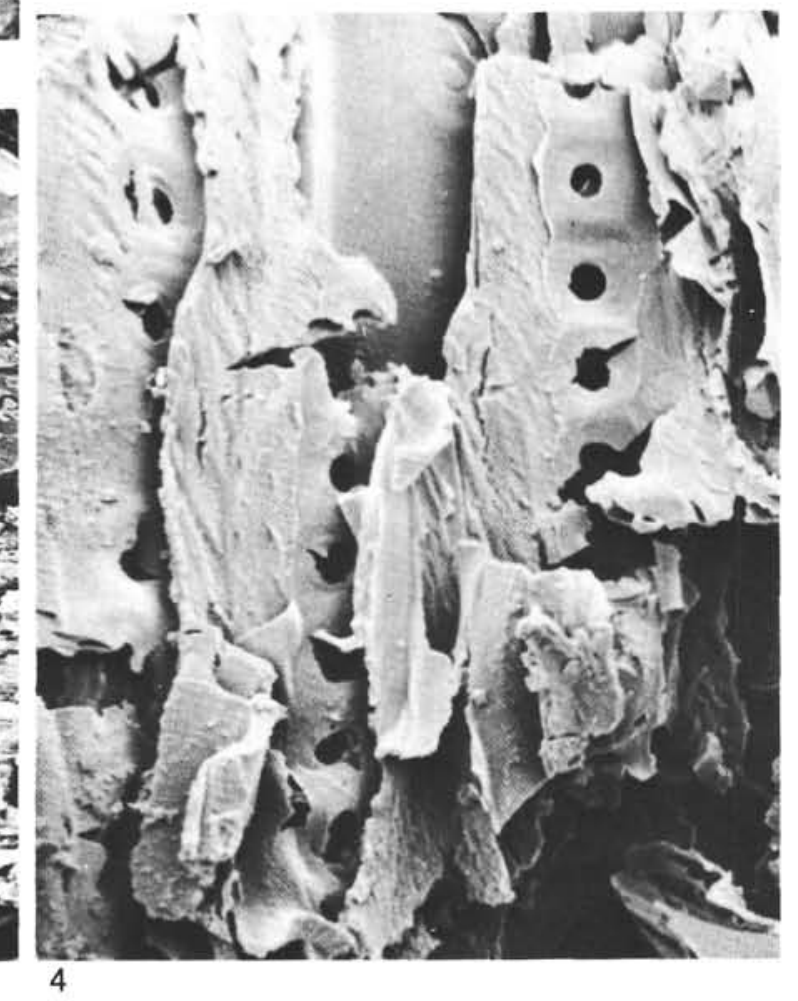

Plate 1. Fragments of wood from the syn-rift Barremian-?Hauterivian sequence at Site 549. 1. Piece of vitrinite, $\times 60$; Sample 549-86-1, 0-125 $\mathrm{cm}$. 2. Detail of same specimen showing typical vitrinite grading upward into less homogeneous material, $\times 230$. 3. Same specimen displaying stratification, $\times 230$. 4. Pitting on tracheid walls compatible with cheirolepidiaceous wood (cf. Fusain Type I, Alvin et al., 1981, p. 767, fig. 3), $\times 1800$; Sample 549-80-1, 118-119 cm. 


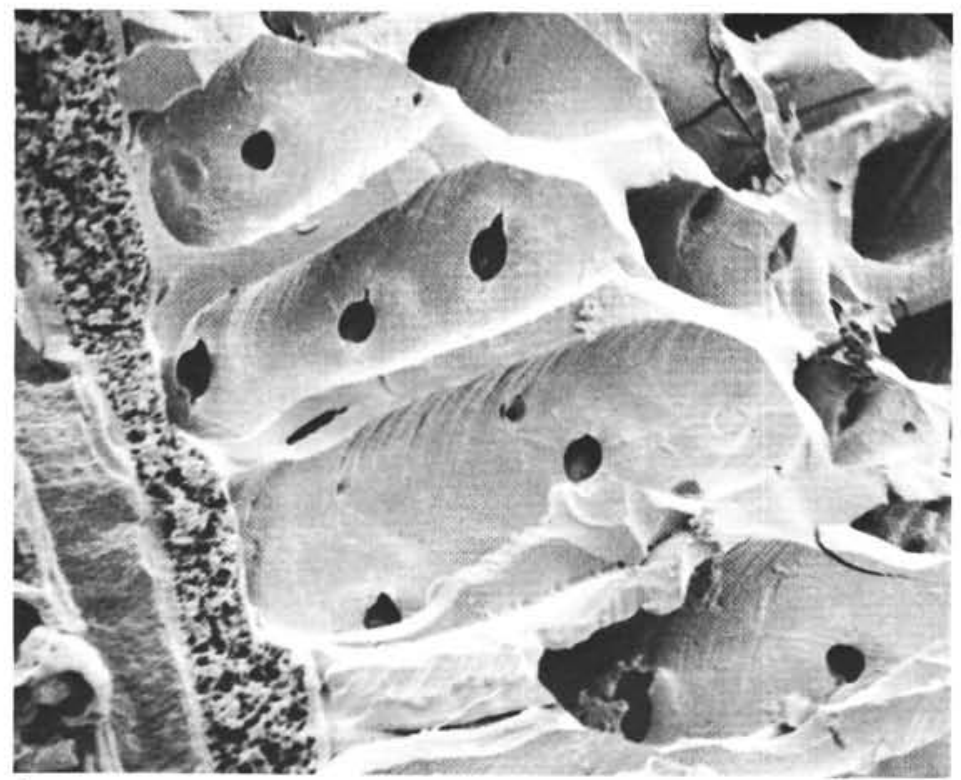

1
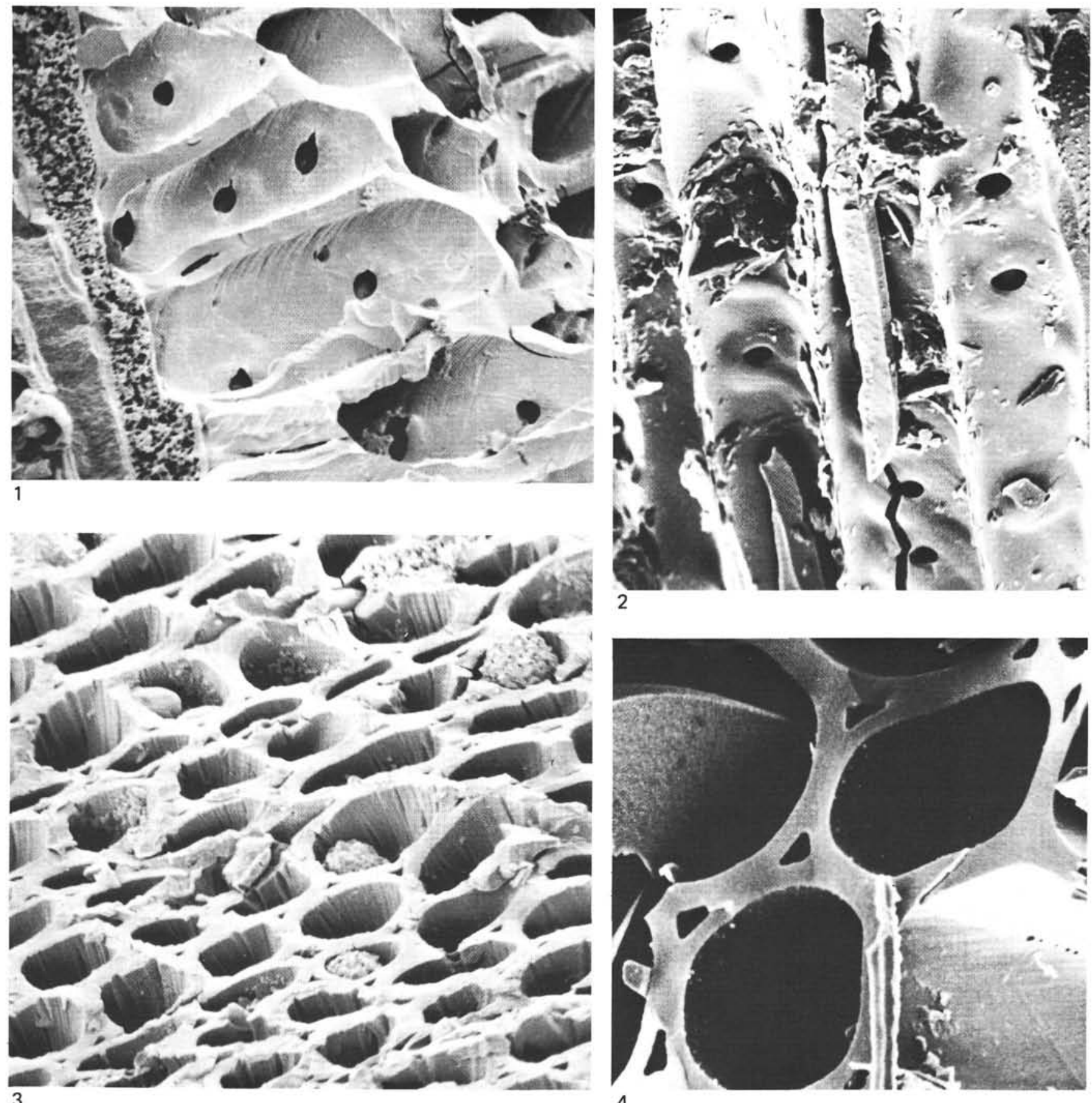

2

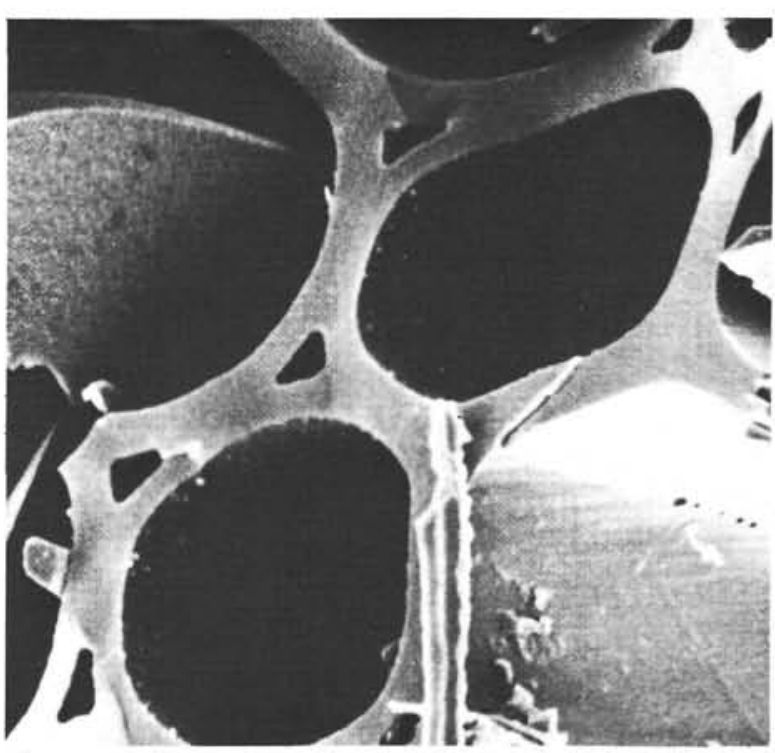

4

Plate 2. Wood fragments from the syn-rift sequence at Site 549. 1, 2. Pitting on tracheid walls compatible with cheirolepidiaceous wood. 1, $\times 1200$; Sample 549-60-4, 80 cm. 2, cf. Fusain Type II in Alvin et al. (1981, p. 769, fig. 6), $\times 1050$; Sample 549-91-1, 9-14 cm. 3, 4. Probable compression wood, similar to Fusain Type III in Alvin et al. (1981, p. 771. fig. 1). 3, ×1100; Sample 549-60-4, 80 cm. 4, $\times 2000$; Sample 54991-1, 9-14 cm. 

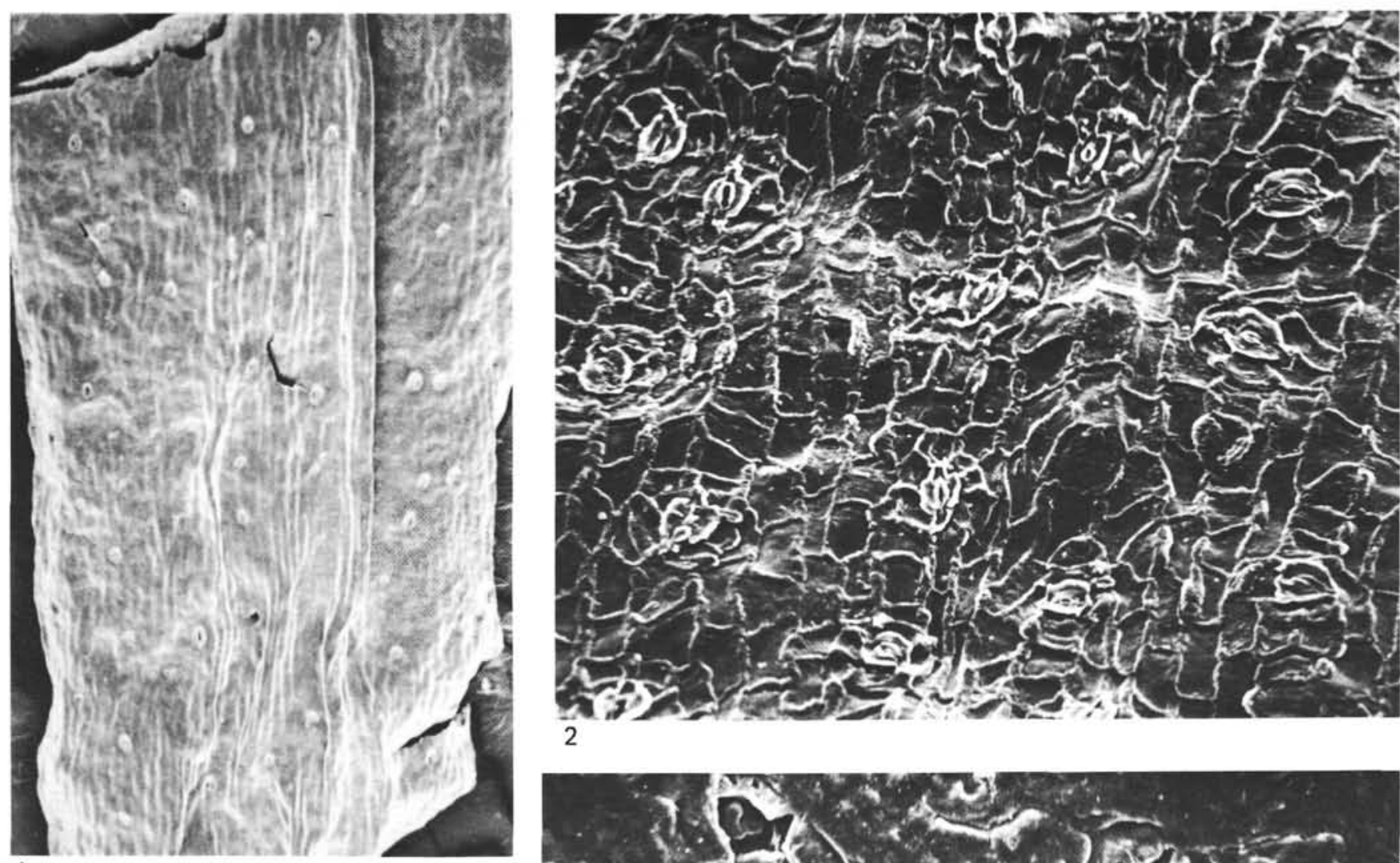

2

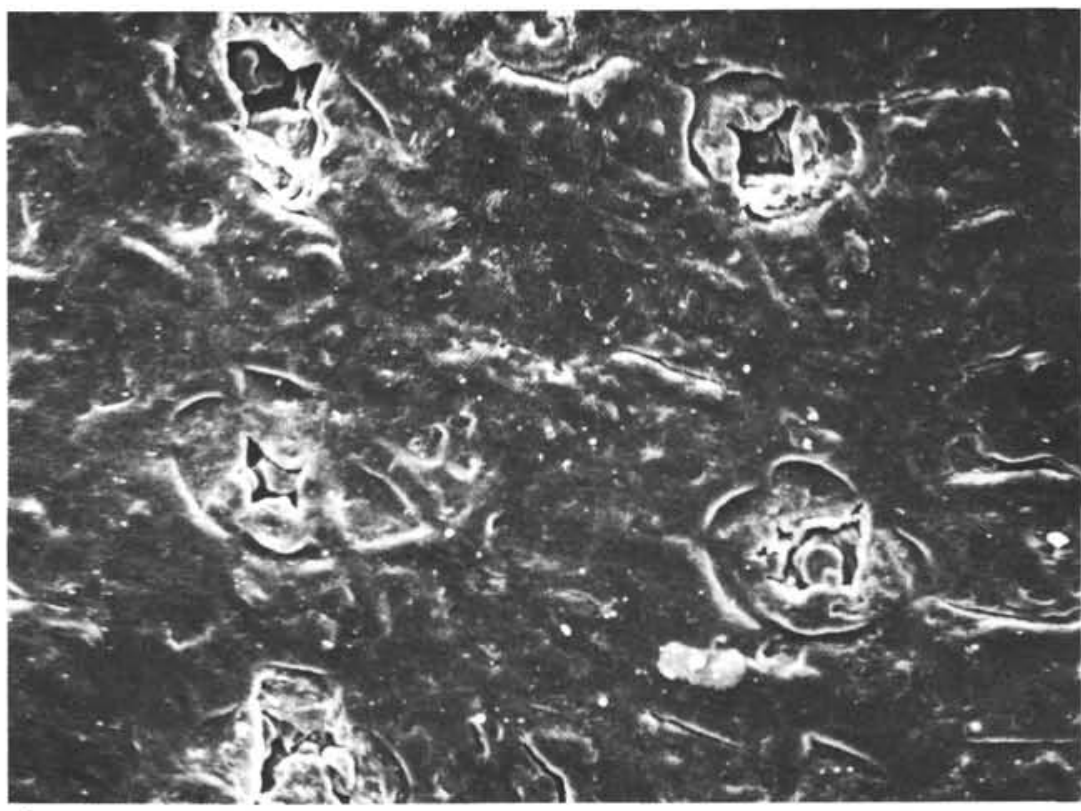

Plate 3. Cuticles from the syn-rift Barremian-?Hauterivian sequence at Site 549. 1. Exterior surface of ginkgophyte cuticle showing sparsely distributed stomata, $\times 50$; Sample 549-91-1, 9-14 cm. 2. Inner surface of ginkgophyte cuticle, $\times 210$; Sample 549-91-1, 9-14 cm. 3. Adaxial cheirolepidiaceous cuticle referred to Frenelopsis sp. 1, displaying surface papillae, $\times 250$; Sample 549-80-1, 130-131 cm. 4. External surface of internode cuticle of Frenelopsis sp. 1 showing stomata, $\times 500$; Sample 549-80-1, 130-131 cm. 

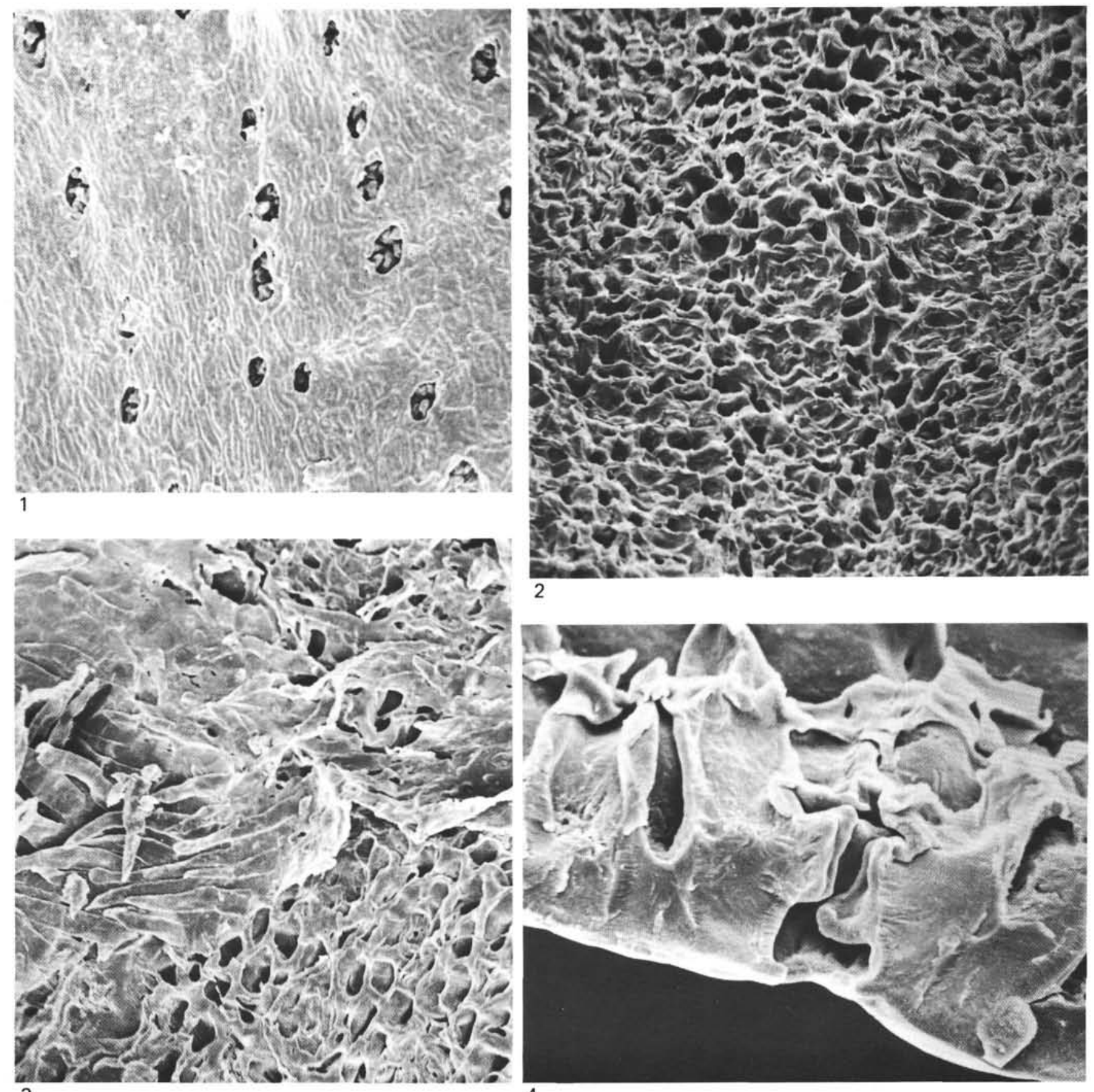
2

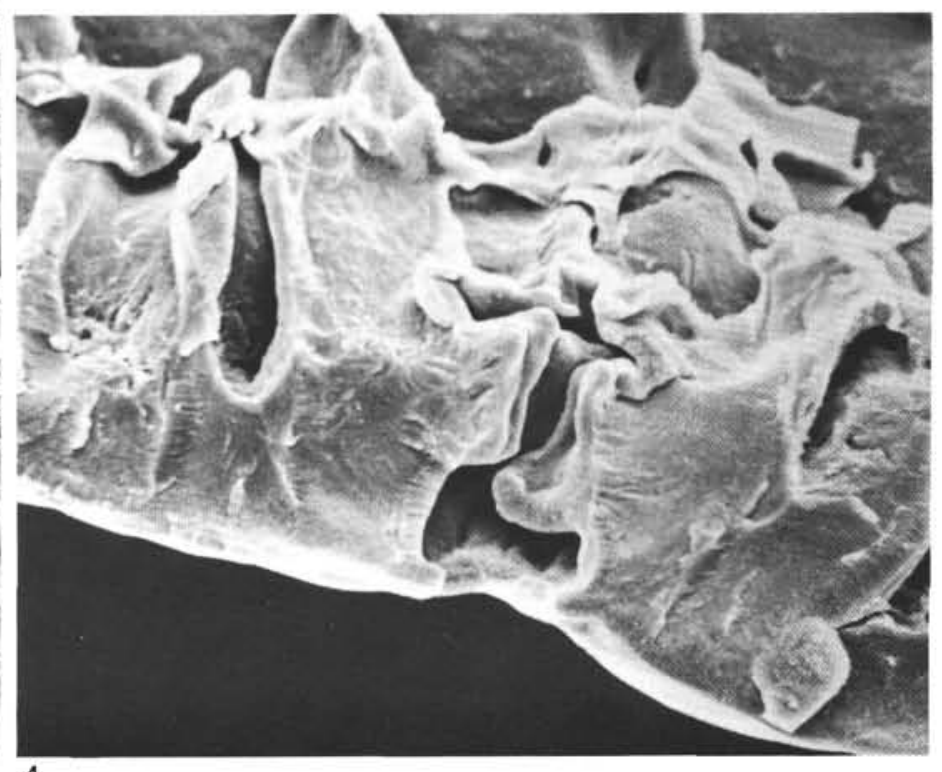

Plate 4. Cuticles referred to Frenelopsis sp. 2 from syn-rift sequence at Site 549 (Sample 549-91-2, 23-25 cm). 1. Outer surface of internode cuticle, $\times 200$. 2. Inner surface of internode cuticle, $\times 180$. 3. Abaxial and adaxial cuticle, $\times 200$. 4. Section of stoma, $\times 1000$. 

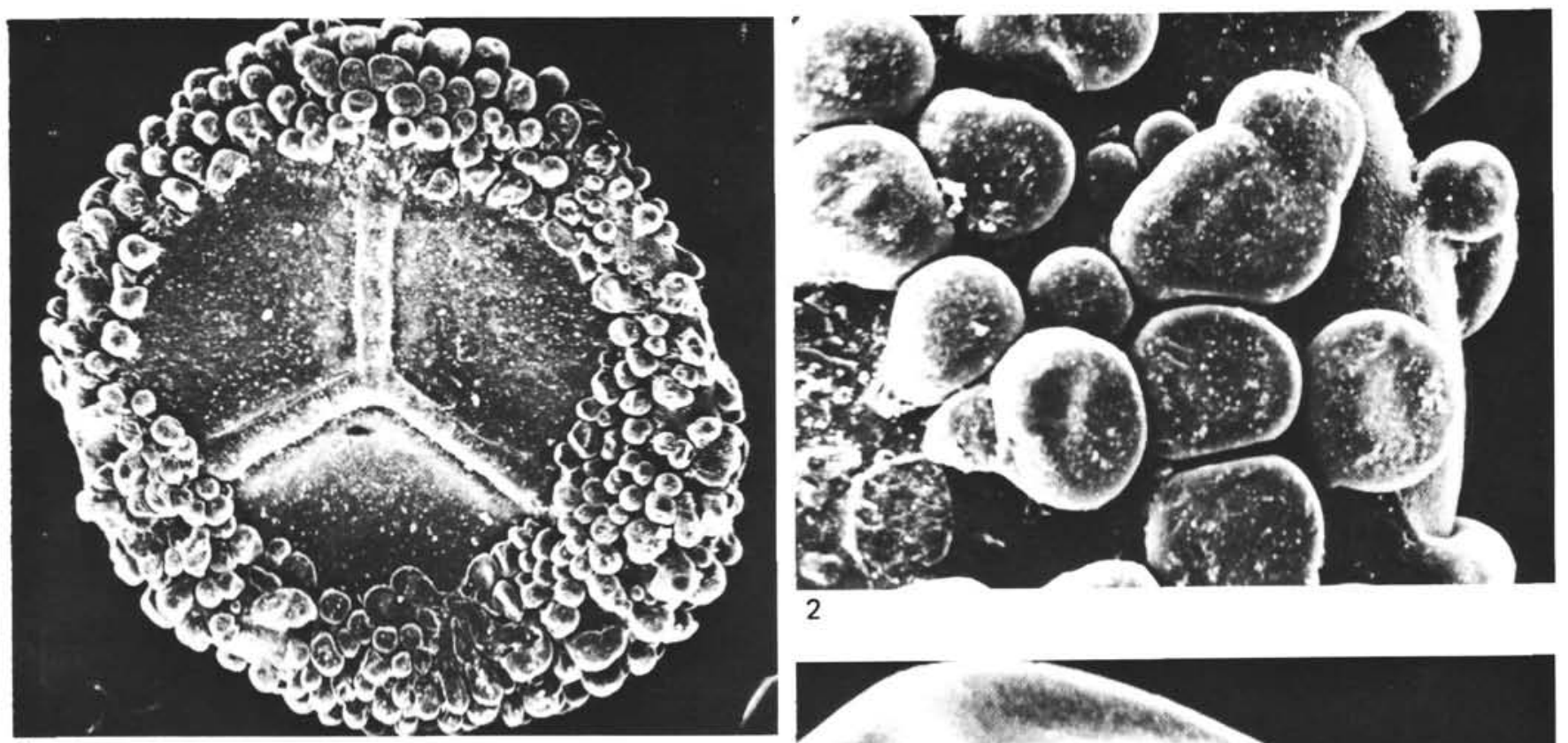

2

1
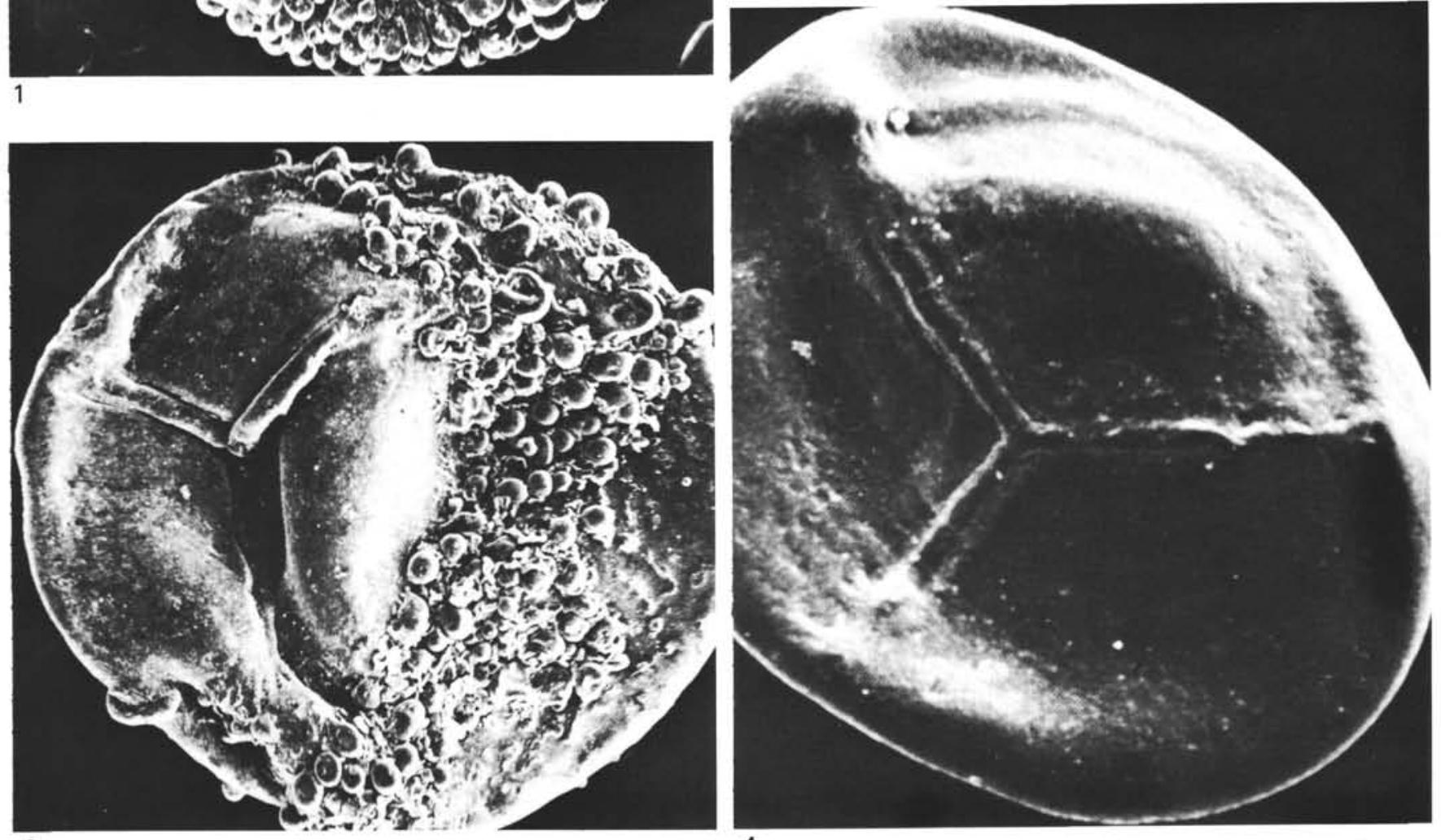

3

4

Plate 5. Megaspores from the syn-rift Barremian-?Hauterivian sequence at Site 549. 1. Verrutriletes carbunculus (Dijkstra)/cf. Trileites murrayi (Harris), $\times 100$; Sample 549-90-2, 110-117 cm. 2. Detail of Fig. 1, $\times 500 . \quad 3$. Verrutriletes carbunculus (Dijkstra)/cf. Trileites murrayi (Harris). The equatorial and distal nodules on this spore are very similar to those considered by Marcinkiewicz (1979) to be the result of fungal attack on $T$. murrayi, $\times 100$; same sample as above. 4. Trileites spurius (Dijkstra), $\times 100$; same sample as above. 

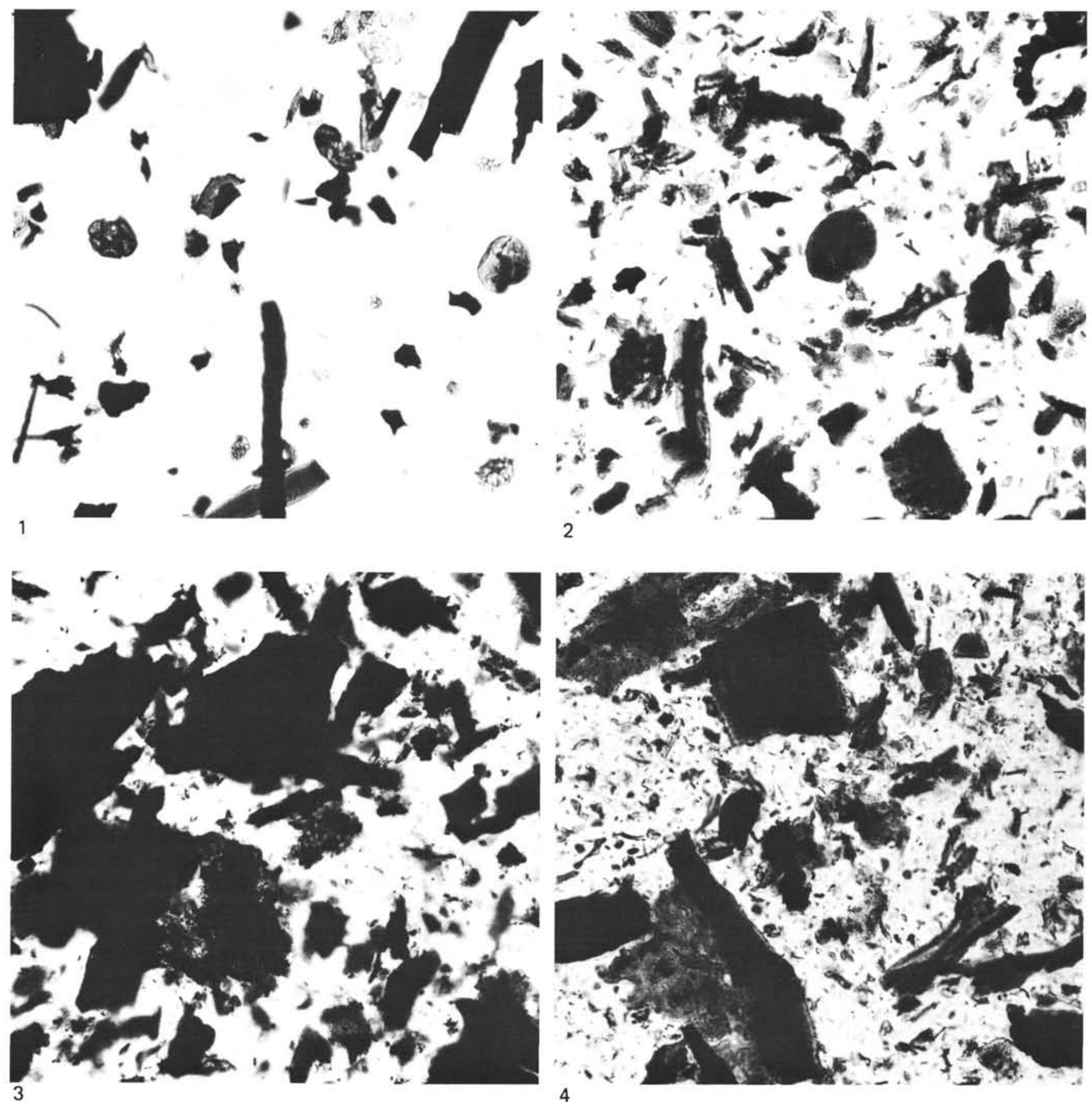

Plate 6. Palynofacies from the earıy Barremian-?Hauterivian syn-rift sequence at Site 549. 1. Near-shore marine palynofacies; dinoflagellate cysts and foraminiferal linings relatively numerous; coaly particles dominate the plant debris assemblage, $\times 150$; Sample 549-92-2, 36-37 cm. Preparation MCP2009, Slide 2, England Finder Reference (EFR) F45/0. 2. Mostly brown woody phytoclasts with well preserved miospores recovered from an apparently nonmarine deposit; fragment of a sporangium (annulus) in top right-hand corner, $\times 150$; Sample 549-92-1, 108-109 $\mathrm{cm}$. Preparation MCP2008, Slide 2, EFR U29/0. 3. Brown-black woody fragments (vitrinite) and amorphous vascular plant matter dominate the preparation; no evidence of marine influence on the depositional environment; source potential for gas is indicated, $\times 150$; Sample 549-91-1, 84-85 cm. Preparation MCP2007, Slide 1, EFR 029/4. 4. As above, but after brief ultrasonic and oxidative treatment; woody tissues are now mostly brown and partly disaggregated, $\times 150$. Preparation MCP2007, Slide 2, EFR U29/0. 

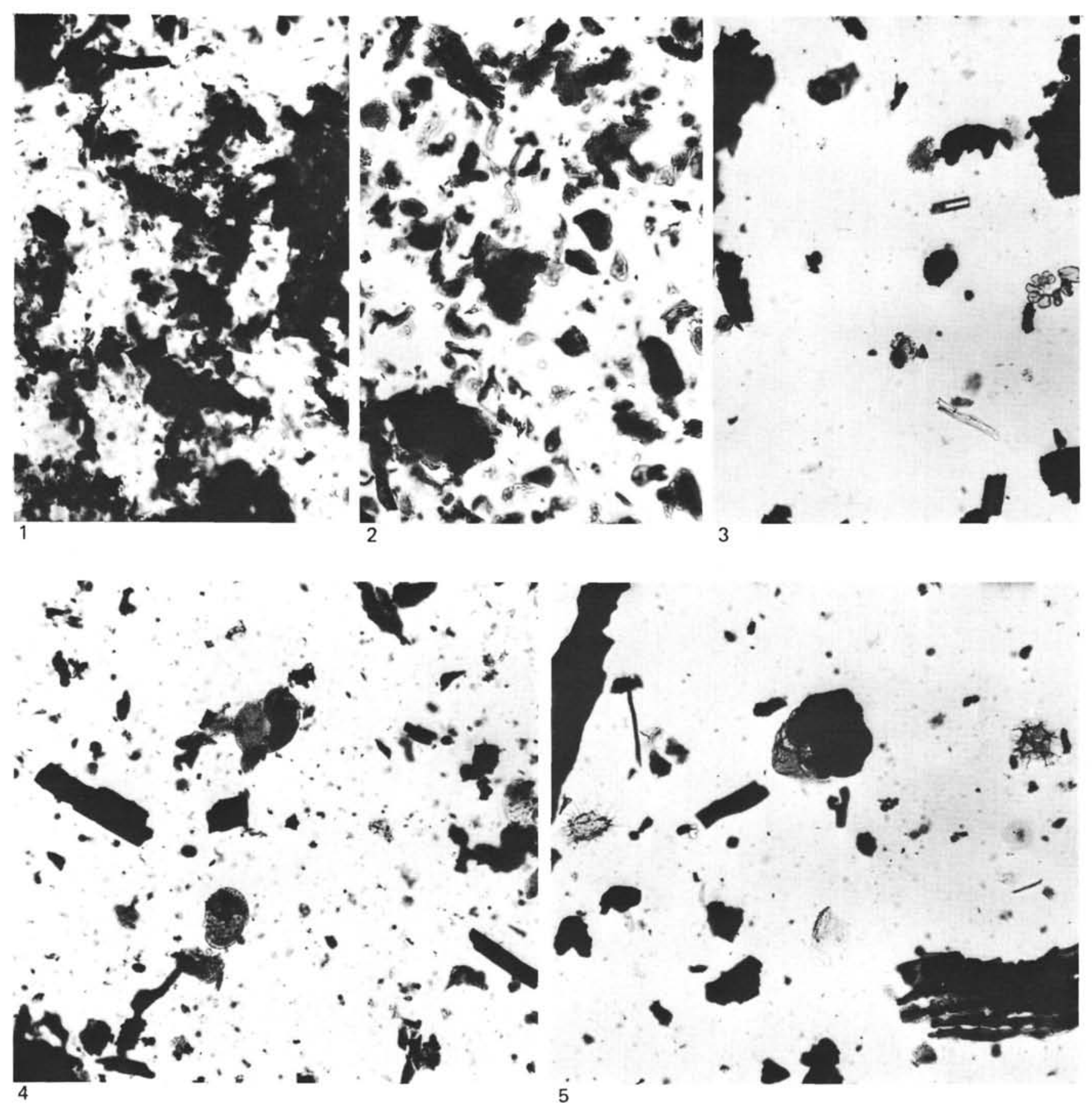

Plate 7. Palynofacies from the Lower Cretaceous syn- and post-rift deposits at Site 549. 1. Finely disseminated amorphous vascular plant matter and brown-black wood (vitrinite) dominate this palynofacies, which suggests source potential for gas, $\times 150$; Sample 549-91-1, 18-20 cm. Preparation MCP2006, Slide 1, EFR V32/0. 2. As above, but after brief oxidation and ultrasonic vibration; amorphous detritus largely removed and woody tissues brown in color, $\times 150$. Preparation MCP2006, Slide 2, EFR U31/0. 3. Palynofacies from the upper part of the Barremian section; general aspect is similar to that of many post-rift Albian preparations, $\times 150$; Sample 549-61-2, 106-108 cm. Preparation MCP1984, Slide 1, EFR 044/4. 4. Bisaccates (Parvisaccites) dominate this Albian palynofacies; black woody-coaly particles abundant, $\times 150$; Sample 549-49-2, $88-89 \mathrm{~cm}$. Preparation MCP1975, Slide 1, EFR S38/2. 5. Typical aspect of Albian post-rift palynofacies prior to brief ultrasonic and oxidative treatment; brown-black woody-coaly particles (some reworked?) with dinoflagellate cysts and foraminiferal linings in association, $\times 150$; Sample 549-37-2, 33-34 cm. Preparation MCP1970, Slide 1, EFR T32/3. 